\title{
Kalianyar Vertical KaMPONg With BeHAVIOR ARCHITECTURE IN JAKARTA
}

\author{
EI Yanno Suminar, Marsudi, Kusumaningdyah Nurul Handayani \\ Program Studi Arsitektur \\ Fakultas Teknik \\ Universitas Sebelas Maret Surakarta \\ Email : el2suminar@yahoo.com
}

\begin{abstract}
Vertical Kampung Kalianyar design was motivated by data and facts related to the city of Jakarta and some issue as a city that has problems of population density. Jakarta is not the only city that has a population density problems, almost all cities in Indonesia have similar problems against the background of the dominance of urbanization which resulted in the high number of population in urban areas. Most of the problems of population density pose problems of urban spatial structure damage caused by the emergence of slum areas or slums in urban areas some point including the city of Jakarta. Kampung is one of the many forms of settlement which is located in the slum area and pay attention to the spatial structure of the city badly. Kampung Kalianyar is one of the densely populated area in the city of Jakarta which has poor spatial structure. On the other hand, as the settlements, Kampung Kalianyar has its own values and character are formed from several things, one of which is a sense of togetherness with the similarity of the social level. Problem of density in Jakarta has tried to be solved by Jakarta Provincial Government with rumah susun program to accommodate flats dense settlements, but it is considered less than optimal because of the character of residents of rumah susun is not contained in it. This is the destination of Kampung Vertical Kalianyar with the basis of behavior architecture as design concept to accommodate the character of Kampung Kalianyar with methods of observation and mapping that is performed directly in Kampung Kalianyar to be applied into a new form named Kampung Vertical Kalianyar. Results from analysis through observation and mapping will be transformed into a new form as knwon as Kampung Vertical Kalianyar which is able to accommodate all the character and behavior of Kampung Kalianyar like life on the road space which has been the character and social value of Kampung Kalianyar and the units of home base enterprises in every floor level.
\end{abstract}

Keywords: Behavior Architecture, Kampung, Kampung Kalianyar, Population Density. Street Space

\section{PENDAHULUAN}

Kepadatan penduduk di Kota Jakarta telah menjadi sebuah fenomena yang tidak dapat diabaikan lagi. Urbanisasi menjadi penyebab terbesar ledakan jumlah penduduk Kota Jakarta di mana angka pertumbuhan arus urbanisasi ke Jakarta hampir mencapai $100 \%$ setiap tahunnya atau sekitar 200.000 sampai 250.000 jiwa datang ke Jakarta. Pada tahun 2050, diperkirakan hampir $85 \%$ penduduk di Indonesia tinggal di perkotaan, tak terkecuali Kota Jakarta (www.katadata.co.id). Kepadatan penduduk cenderung menjadi sumber masalah di Kota Jakarta, salah satunya adalah masalah munculnya slum area di beberapa titik Kota Jakarta akibat dari keterbatasan lahan di Kota Jakarta. Slum area banyak memanfaatkan ruang terbuka hijau di mana angka RTH Kota Jakarta saat ini sudah semakin kritis yaitu 9,8\% dari target yang ditetapkan pemerintah dalam UU No. 26 Tahun 2007 yaitu sekurang-kurangnya $30 \%$ bagi setiap kota (Kata Fakta Jakarta, 2011). Hal ini menjadikan struktur tata ruang kota menjadi lebih rumit dan tidak teratur.

Maraknya slum area yang menjadi salah satu masalah struktur tata ruang kota didominasi oleh permukiman penduduk dengan tingkat ekonomi menengah ke bawah yang banyak disebut sebagai kampung. Kampung menurut Turner (1972) merupakan kawasan permukiman kumuh dengan ketersediaan sarana umum buruk atau tidak ada sama sekali, kerap kawasan ini disebut slum atau squater. Menurut pakar perkotaan Budiharo (2004), kampung merupakan kawasan hunian masyarakat 
berpenghasilan rendah dengan kondisi fisik yang kurang baik.

Kampung Kalianyar atau Kelurahan Kalianyar merupakan salah satu permukiman dengan tingkat kepadatan yang sangat tinggi dan memiliki struktur tata ruang yang kurang baik. Hal ini tercermin dari bagaimana pola penataan ruang di kampung yang sangat rumit dan juga sempit. Beberapa sarana dan prasarana penunjang juga tidak optimal seperti keberadaan ruang terbuka hijau yang sangat minim di Kelurahan Kalianyar. Kelurahan Kalianyar merupakan kelurahan yang terkenal padat di Jakarta, berdasarkan survey UNDP tahun 2008, Kelurahan Kalianyar adalah salah satu kawasan terdapat di Asia Tenggara (www.kectambora.com). Konsep vertikal dianggap mampu menjadi solusi dalam penataan Kampung Kalianyar, selain dapat menjadikan tata ruang kampung yang lebih baik, konsep vertikal juga mampu membuka ruang terbuka baru sebagai area hijau dan area resapan air. Hal senada juga tertuang dalam Rencana Tata Ruang Wilayah Kota Jakarta tahun 2030 di mana Kelurahan Kalianyar masuk ke dalam wilayah yang diperuntukkan sebagai permukiman, lebih jauh lagi sebagai permukiman vertikal.

Pemerintah Provinsi DKI Jakarta telah mengeluarkan solusi berupa sebuah hunian vertikal yang banyak dikenal dengan sebutan rumah susun, namun rumah susun yang menjadi solusi PemProv dianggap belum optimal dan banyak ditinggalkan oleh penghuninya. Permasalahan umum yang terjadi adalah kurang terwadahinya perilaku masyarakat atau warga yang menjadi penghuni. Menurut Eko Prawoto pada acara Jakarta Vertikal Kampung di Erasmus Huis, Kedutaan Besar Belanda, Jakarta, "Yang terpenting bukan pada fisiknya, vertikal atau horizontal hanya pilihan, tapi bangunan tersebut dibangun untuk siapa. Kita harus menyediakan tempat yang sesuai dengan kebutuhan penghuni, karena tidak sekadar memindahkan orang, tapi juga memindahkan kehidupan yang sarat nilai, dan persepsi" (www.beritasatu.com). Karakter perilaku kampung menjadi nilai yang tidak dapat ditinggalkan.

\section{METODE}

Metode perancangan yang dilakukan adalah rangkaian proses desain yang berorientasi pada pengolahan data, baik itu data primer dan sekunder yang telah dilakukan sebelumnya untuk kemudian ditransformasikan ke dalam sebuah desain. Adapun beberapa rangkaian proses tersebut adalah

A. Melakukan Pengamatan dan Pemetaan

\section{(Mapping)}

Hal yang pertama dilakukan adalah melakukan pengamatan dan juga pemetaan di Kampung Kalianyar sebagai eksisting kampung yang menjadi objek perancangan kampung vertikal. Pengamatan yang dilakukan berupa pengamatan kondisi fisik kampung terkait dengan perasaan meruang di lokasi. Pemetaan dilakukan dengan mengamati kondisi fisik dan non fisik. Kondisi fisik yang diamati adalah elemen pembentuk kampung, baik sarana dan prasarana, fungsi, serta dimensi sedangkan non fisik berupa kegiatan dan interaksi sosial warga kampung.

B. Menerjemahkan atau Transformasi.

Setelah melakukan pengamatan dan pemetaan, serta mendalami literatur, isu, serta kondisi terkini, maka disimpulkan setidaknya terdapat tiga faktor yang menjadi dasar dalam transformasi desain untuk diterjemahkan ke dalam desain yang baru (Gambar 1).

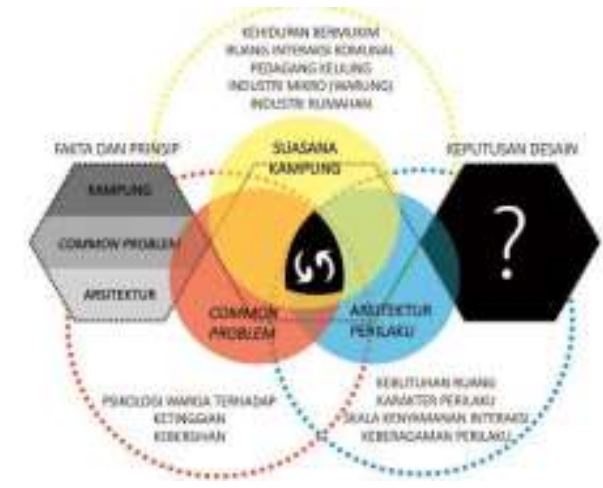

Gambar 1. Faktor Transformasi Desain

\section{Desain Mikro (Hunian)}

Desain mikro yaitu berupa hunian yang memiliki standar ruang tertentu serta memiliki nilai yang terkandung dari pengalaman hidup di Kampung Kalianyar sebelumnya. Hasil pengamatan yang dipetik pada proses sebelumnya, yaitu warga kampung memiliki 
keberagaman karakter sehingga desain yang direncanakan memiliki fleksibilitas ruang.

D. Desain Mezo (Modul Blok Hunian)

Setelah hunian, hal selanjutnya adalah mengolah modul hunian yang menjadi kumpulan dari setiap hunian dalam bentuk vertikal. Dalam proses ini, studi bentuk modul blok hunian menggunakan ilustrasi melalui $3 D$ modelling atau maket (Gambar 2).

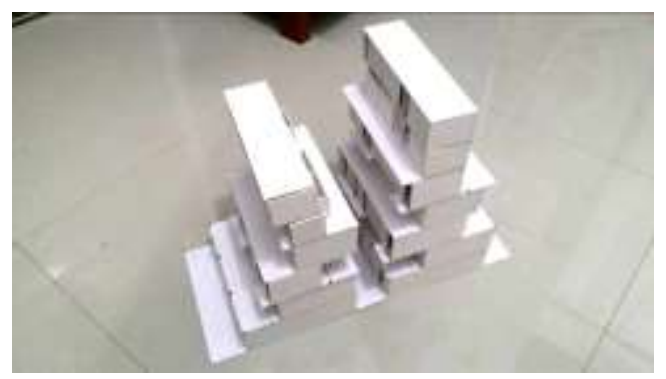

Gambar 2. Studi Gubahan Massa

Desain ruang jalan yang menjadi karakter Kampung Kalianyar menjadi prioritas guna menghadirkan ruang interaksi di setiap lantai pada modul blok hunian Kampung Vertikal Kalianyar.

\section{E. Desain Makro (Tapak)}

Setelah desain modul blok hunian, hal yang selanjutnya diolah adalah perancangan tapak di mana seluruh komponen ruang termasuk modul blok hunian ditempatkan dalam tapak. Penempatan komponen ruang didasarkan pada analisis zonasi yang dilakukan dalam beberapa pertimbangan, termasuk analisis klimatologis serta interaksi tapak dengan lingkungan sekitar.

\section{ANALISIS}

A. Analisis Penentuan Lokasi dan Kondisi Eksisting

Analisis pemilihan lokasi meliputi data terkait legalitas serta hasil pemetaan (mapping) kondisi kampung.

1. Tujuan :

Mendapatkan lokasi potensial sebagai lokasi perencanaan Kampung Vertikal

2. Dasar pertimbangan :
Termasuk dalam permukiman padat penduduk, termasuk dalam program hunian vertikal.

3. Proses Analisis :

Kampung Kalianyar merupakan kawasan di Kecamatan Tambora yang merupakan kawasan terpadat (RTRW Tahun 2010 Kota Jakarta)

Kampung Kalianyar termasuk ke dalam program hunian vertikal dalam RTRW tahun 2030 Kota Jakarta.

RW 01 sebagai RW terpadat di Kelurahan Kalianyar. Kondisi fisik dan non fisik diamati dengan melakukan pemetaan (mapping) ke lokasi.

Kondisi fisik berupa sarana dan prasarana, dan elemen yang ada di Kampung Kalianyar. Kondisi non fisik berupa karakter perilaku warga kampung (Gambar 3).
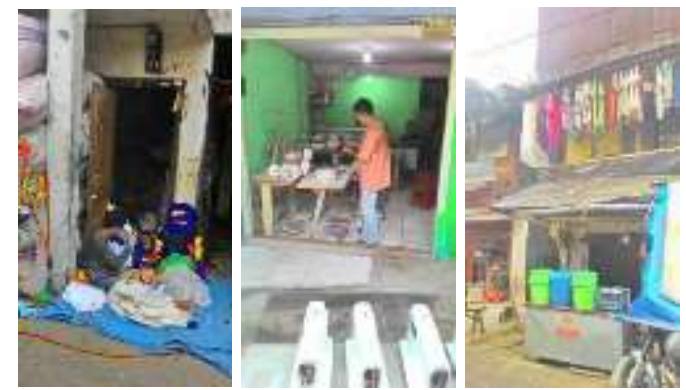

Gambar 3. Kondisi Fisik RW01

Kondisi non fisik berupa ruang komunal atau ruang-ruang bersama yang tercipta akibat interaksi antar warga kampung (Gambar 4).

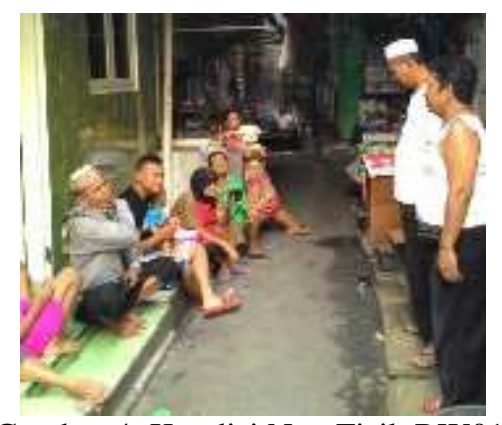

Gambar 4. Kondisi Non Fisik RW01

B. Analisis Pencapaian 
Analisis pencapaian didapatkan berdasarkan analisis kondisi jaringan jalan dan sirkulasi makro di luar tapak.

1. Tujuan :

Menentukan letak akses masuk menuju lokasi berupa main entrance (ME) dan side entrance (SE).

2. Dasar pertimbangan:

Kemudahan akses, pencapaian utama (ME) yang aman dan terbebas dari titik keramaian jalan, pencapaian alternatif (SE) cenderung digunakan untuk akses servis.

3. Proses Analisis :

Pencapaian memanfaatkan jalan di sisi kanal sebagai jalan besar untuk menjadi akses pencapaian utama (Main Entrance).

Pencapaian alternatif (Side Entrance) dibuat di sisi timur, sebagai respon adanya sirkulasi utama Kelurahan Kalianyar (Gambar 5).

Pencapaian alternatif (SE) di sisi timur juga difungsikan sebagai akses servis.

Pencapaian alternatif di sisi utara dan selatan merupakan akses pejalan kaki dengan ruang interaksi sebagai ruang penghubung.

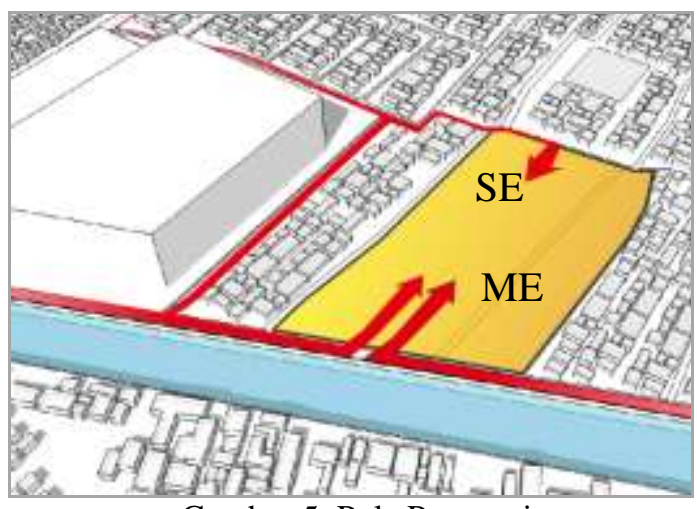

Gambar 5. Pola Pencapaian

C. Analisis Kebutuhan Ruang Analisis ini merupakan proses guna mendapatkan hasil berupa wadah yang mampu menjadikan Kampung Vertikal Kalianyar memiliki karakter yang sesuai dengan kondisi kampung eksisting.
1. Tujuan :

Menentukan ruang-ruang yang ada di Kampung Vertikal Kalianyar berdasarkan hasil pola kegiatan yang ada di RW 01 Kelurahan Kalianyar.

2. Dasar Pertimbangan :

Berperan sebagai wadah dari pola kegiatan yang ada, kehidupan bermukim menjadi prioritas, kehidupan industri atau komersial rumahan menjadi bagian tak terpisahkan, kebutuhan ruang sesuai standar perencanaan dan perancangan permukiman.

3. Proses Analisis :

Pola kegiatan warga yang sudah terbentuk di Kampung Kalianyar akan diwadahi sesuai dengan kondisi eksisting (Tabel 1).

Kegiatan baru muncul seiring dengan hadirnya pelaku kegiatan baru seperti pengelola kampung vertikal.

Sarana dan prasarana penunjang yang kondisinya tidak optimal atau bahkan tidak ditemukan keberadaannya pada kondisi eksisting akan dihadirkan sesuai standar sebagai sarana dan prasarana tambahan (Tabel 2).

Tabel 1. Kebutuhan Ruang

\begin{tabular}{|c|c|c|}
\hline $\begin{array}{c}\text { PELAKU } \\
\text { KEGIATAN }\end{array}$ & KEGIATAN & $\begin{array}{c}\text { KEBUTUHAN } \\
\text { RUANG }\end{array}$ \\
\hline \multirow{5}{*}{$\begin{array}{l}\text { Penghuni } \\
\text { Kampung } \\
\text { Vertikal }\end{array}$} & Bermukim & Unit Hunian \\
\hline & Bekerja & $\begin{array}{l}\text { di luar } \\
\text { Lingkungan }\end{array}$ \\
\hline & Berdagang & Area Komersial \\
\hline & Berindustri & Area Industri \\
\hline & Bersosialiasi & Ruang Publik \\
\hline \multirow{3}{*}{$\begin{array}{l}\text { Pengelola } \\
\text { Kampung } \\
\text { Vertikal }\end{array}$} & Bekerja & Kantor Pengelola \\
\hline & $\begin{array}{l}\text { Mengontrol } \\
\text { Unit Fasilitas }\end{array}$ & Ruang Servis \\
\hline & Bersosialisasi & Ruang Publik \\
\hline \multirow{2}{*}{$\begin{array}{l}\text { Pekerja } \\
\text { Industri } \\
\text { Rumahan }\end{array}$} & Bekerja & $\begin{array}{l}\text { Unit Industri/ Unit } \\
\text { Komersial }\end{array}$ \\
\hline & Bersosialiasi & Ruang Publik \\
\hline \multirow[t]{5}{*}{ Pengunjung } & Bertamu & Unit Hunian \\
\hline & $\begin{array}{l}\text { Berkunjung } \\
\text { Ke Kantor } \\
\text { Pengelola } \\
\end{array}$ & Kantor Pengelola \\
\hline & $\begin{array}{l}\text { Mengantar } \\
\text { Barang }\end{array}$ & $\begin{array}{l}\text { Unit Industri/Unit } \\
\text { Komersial }\end{array}$ \\
\hline & Berdagang & Area Berdagang \\
\hline & Bersosialisasi & Ruang Publik \\
\hline
\end{tabular}


Tabel 2. Sarana Tambahan

\begin{tabular}{|l|l|l|}
\hline \multicolumn{1}{|c|}{ SARANA } & KENDALA & \multicolumn{1}{c|}{ SOLUSI } \\
\hline Pasar & Tidak ada & $\begin{array}{l}\text { Menyediakan } \\
\text { pasar sebagai } \\
\text { wadah, } \\
\end{array}$ \\
& & $\begin{array}{l}\text { fungsinya dapat } \\
\text { digabung } \\
\text { dengan ruang } \\
\text { publik }\end{array}$ \\
& & $\begin{array}{l}\text { Fungsinya } \\
\text { dapat digabung } \\
\text { dengan masjid }\end{array}$ \\
\hline Balai Warga & Tidak ada & $\begin{array}{l}\text { Keberadaannya } \\
\text { dapat menjadi } \\
\text { area interaksi } \\
\text { dengan } \\
\text { Tamang }\end{array}$ \\
Terbuka/ & Tidak ada & $\begin{array}{l}\text { lingkungan } \\
\text { sekitar }\end{array}$ \\
\hline Raga & & \\
\hline
\end{tabular}

D. Analisis Bentuk Dasar Ruang

Proses analisis ini sebagai respon desain terhadap pola hubungan antar ruang. Analisis bentuk dasar yang dilakukan meliputi bentuk dasar unit hunian.

1. Tujuan :

Menghasilkan bentuk dasar ruang guna menyajikan ilustrasi desain tiap unit hunian.

2. Dasar Pertimbangan :

Memiliki karakter fleksibilitas ruang, mengakomodasi pola hubungan ruang yang telah dianalisis sebelumnya, alternatif desain dapat menjadi solusi untuk menawarkan keberagaman desain.

3. Proses Analisis :

Pola hubungan ruang merupakan respon dari kebutuhan ruang yang telah diorganisir pada analisis sebelumnya (Gambar 6).

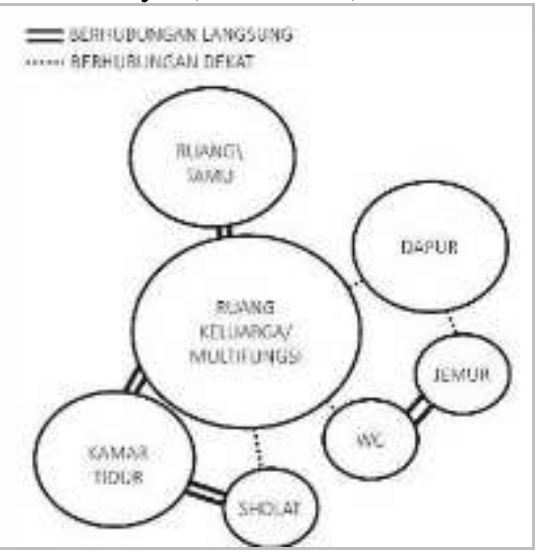

Gambar 6. Organisasi Ruang Unit Hunian
Variasi bentuk dasara ruang unit hunian merupakan feedback dari analisis bentuk modul hunian.

Tipologi dari setiap unit hunian merupakan respon dari data Kelurahan Kalianyar terkait jenis hunian yang ada di Kelurahan Kalianyar, yaitu :

- Permanen : 40\% (Tipe A)

- Semi Permanen : $57 \%$ (Tipe B)

- Non Permanen : $3 \%$ (Tipe C)

(Sumber : www.kectambora.com)

Setiap unit memiliki alternatif dalam hal penataan ruang sebagai wujud fleksibilitas ruang yang mewadahi keberagaman perilaku warga (Gambar 7,8\&9)

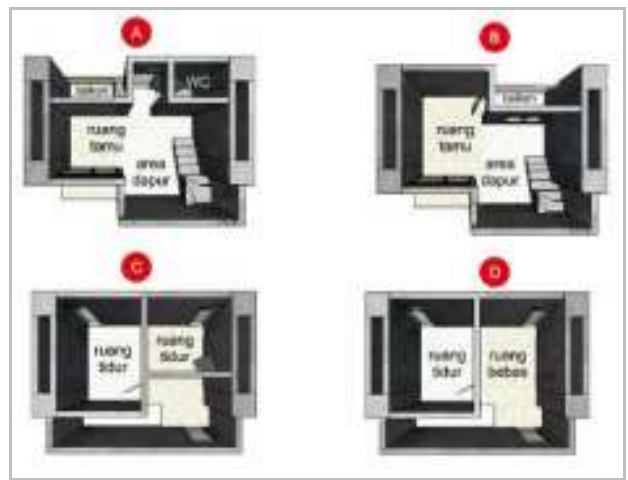

Gambar 7. Bentuk Dasar Ruang Unit $1=30 \mathrm{~m} 2+10$ m2 (2 Lantai)

(A) Unit 1 tipe $A$

(B) Unit 1 tipe $B$

(C) Alternatif 1 Lantai 2 Unit 1 dengan 2 Kamar Tidur

(D) Alternatif 2 lantai 2 Unit 1 dengan 1 Kamar Tidur

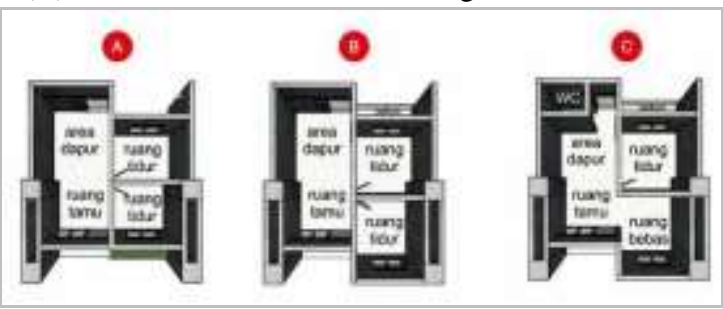

Gambar 8. Bentuk Dasar Ruang Unit $2=30 \mathrm{~m} 2$

(A) Tipe $\mathrm{C}$ dengan Alternatif 2 Kamar Tidur

(B) Tipe B dengan Alternatif 2 Kamar Tidur

(C) Tipe A dengan Alternatif 1 Kamar Tidur 


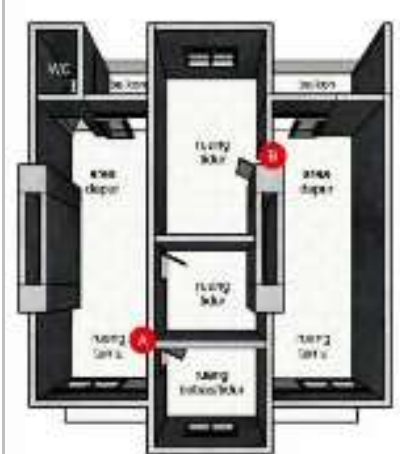

Gambar 9. Bentuk Dasar Ruang Unit $3=30$ m2 Model "L"

(A) Tipe A dengan Alternatif 2 Kamar Tidur/1 Ruang Bebas

(B) Tipe B dengan Alternatif 1 Kamar Tidur

E. Analisis Modul Hunian

Analisis ini menekankan pada proses olah bentuk modul blok hunian.

1. Tujuan :

Mendapatkan konsep modul yang sesuai dengan karakter kampung baik dari segi bentuk dan fungsi.

2. Dasar Pertimbangan :

Jumlah lantai sesuai dengan peraturan, bentuk dasar mampu mewadahi karakter kampung sesuai dengan prinsip Arsitektur Perilaku (Synder, 1989 dalam Marcella, 2004), "sebagai manusia pasti memiliki kebutuhan dasar yang harus dipenuhi, salah satunya phsycological need.

3. Proses Analisis :

Sesuai dengan Peraturan Menteri PU No. 05/Prt/M/2007, jumlah lantai maksimal bangunan tanpa lift adalah 6 lantai. Bentuk berundak mampu meminimalisir dampak psikologi warga terhadap ketinggian (Gambar 10).

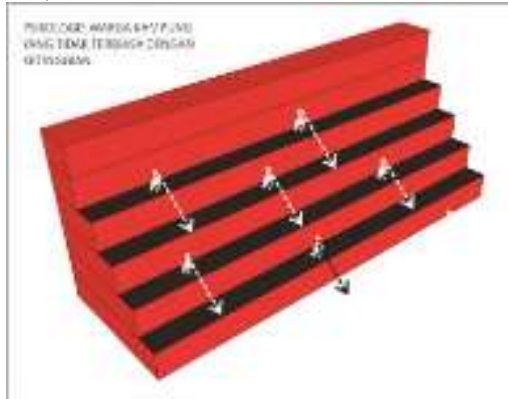

Gambar 10. Bentuk Berundak sebagai Bentuk Dasar
Ruang jalan yang menjadi karakter Kampung Kalianyar, dapat diterapkan pada setiap lantai. Interaksi antar lantai diterapkan pada void interaksi dengan interaksi zig-zag (Gambar 11).

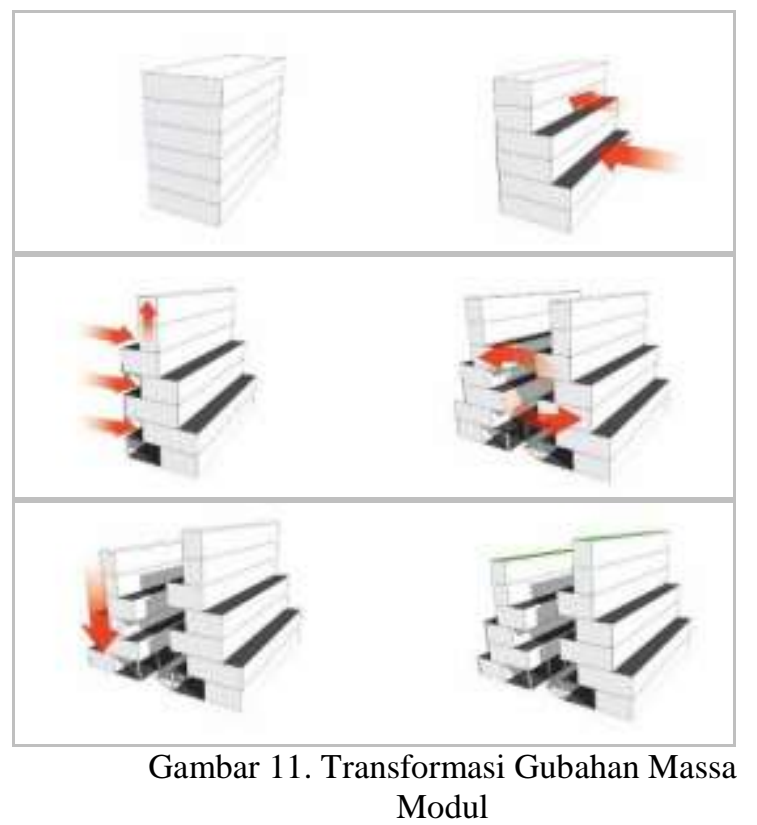

Faktor klimatologis menjadi analisis terkait kenyamanan termal unit hunian di dalam modul seperti matahari, angin, hujan, dan radiasi akan menjadi faktor klimatologis yang dianalisis (Gambar 12).

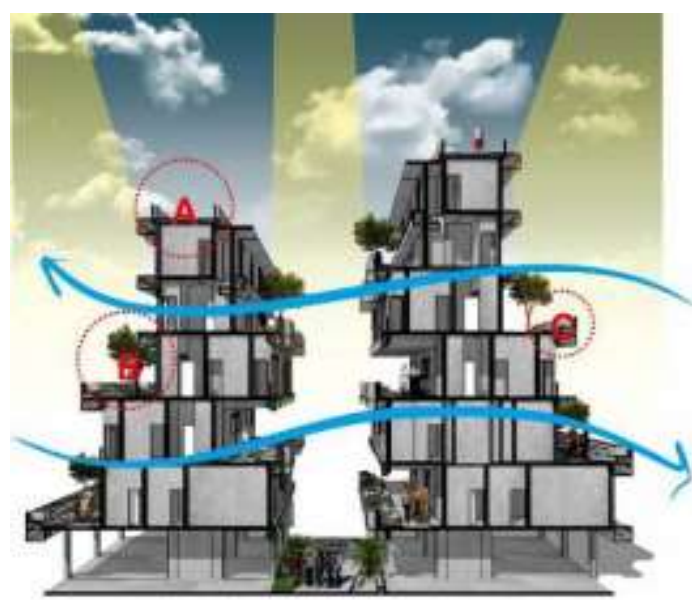

Gambar 12. Analisi Klimatologis (A) Green Roof untuk Mencegah Radiasi

(B) Vegetasi sebagai Penghalau Sinar Matahari (C) Tritisan untuk Mencegah Air Hujan 
Zonasi pada modul direncanakan mampu mewadahi seluruh karakter Kampung Kalianyar (Tabel 3), salah satunya adalah penempatan unit industri rumahan serta unit komersial (Gambar 13).

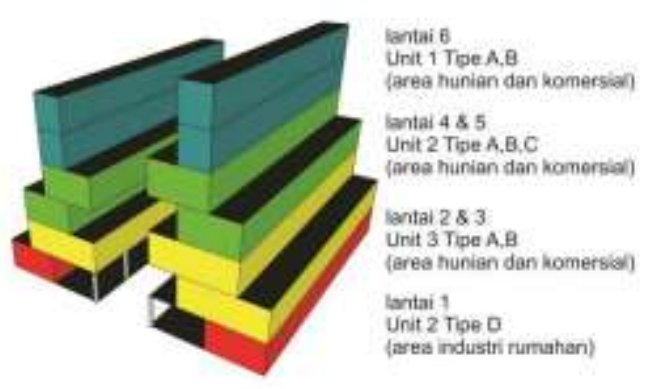

Gambar 13. Zonasi pada Modul Hunian

Tabel 3. Zonasi Unit dalam Modul

\begin{tabular}{|c|c|c|}
\hline $\begin{array}{c}\text { UNIT } \\
\text { BERMUKIM }\end{array}$ & $\begin{array}{c}\text { UNIT } \\
\text { INDUSTRI }\end{array}$ & $\begin{array}{c}\text { UNIT } \\
\text { KOMERSIAL }\end{array}$ \\
\hline $\begin{array}{l}\text { Tersebar di } \\
\text { seluruh lantai } \\
\text { modul hunian. } \\
\text { Tipe A dan B } \\
\text { berada di lantai } \\
2 \text { sampai lantai } \\
\text { 6. Sedangkan } \\
\text { tipe c } \\
\text { keberadaannya } \\
\text { hanya di lantai } \\
2,3 \text {, dan } 4 \text { atau } \\
\text { pada unit } 2 \text { saja. }\end{array}$ & $\begin{array}{l}\text { Hanya } \\
\text { terletak } \\
\text { pada lantai } \\
\text { dasar } \\
\text { mengingat } \\
\text { kemudahan } \\
\text { akses dan } \\
\text { kemudahan } \\
\text { bongkar } \\
\text { muatan } \\
\text { sangat } \\
\text { diperlukan. }\end{array}$ & $\begin{array}{l}\text { Tersebar di setiap } \\
\text { lantai dengan } \\
\text { jumlah dan jenis } \\
\text { yang beragam, } \\
\text { sesuai dengan } \\
\text { keadaan eksisting }\end{array}$ \\
\hline
\end{tabular}

\section{F. Analisis Tata Tapak}

Analisis ini merupakan respon setelah analisis bentuk dasar ruang dan modul telah dilakukan. Analisis ini akan menghasilkan tata massa Kampung Vertikal Kalianyar.

1. Tujuan :

Mendapatkan zonasi hasil dari beberapa faktor.

2. Dasar Pertimbangan :

Zoning merupakan hasil dari beberapa analisis beberapa faktor seperti sirkulasi, kegiatan, dan klimatologis. Tata massa merespon kondisi kawasan sekitar.

3. Proses Analisis :

Analisis zonasi terkait sirkulasi di dalam tapakdilakukan dengan menentukan pola sirkulasi yang merespon letak ME dan SE (Gambar 14).
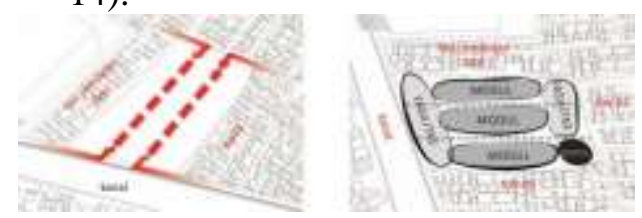

Gambar 14. Zoning terkait Sirkulasi

Analisis terkait kegiatan sejenis dilakukan dengan merespon pola hubungan ruang dari hubungan sejenis (Gambar 15).

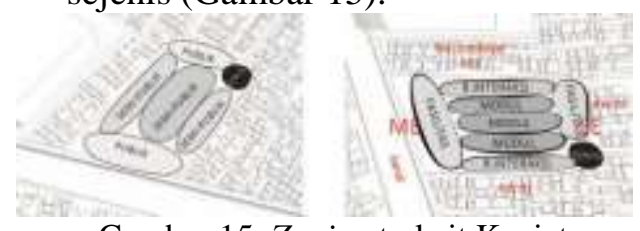

Gambar 15. Zoning terkait Kegiatan Sejenis

Analisis zonasi terkait faktor klimatologis meliputi analisis sinar matahari serta arah sirkulasi angin (Gambar 16).

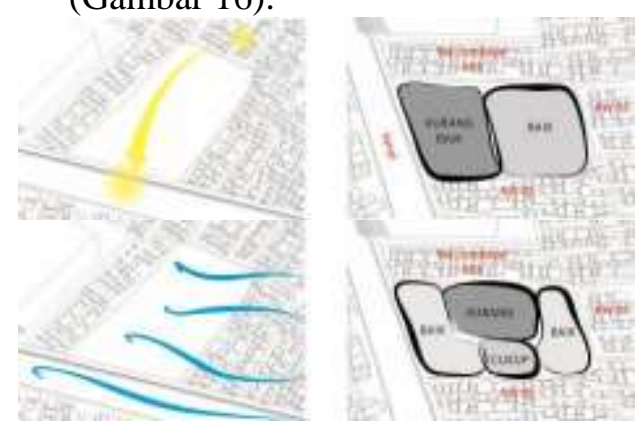

Gambar 16. Zoning terkait Klimatologis

Zoning akhir merupakan hasil kesimpulan dari beberapa zoning terhadap beberapa faktor (Gambar 17).

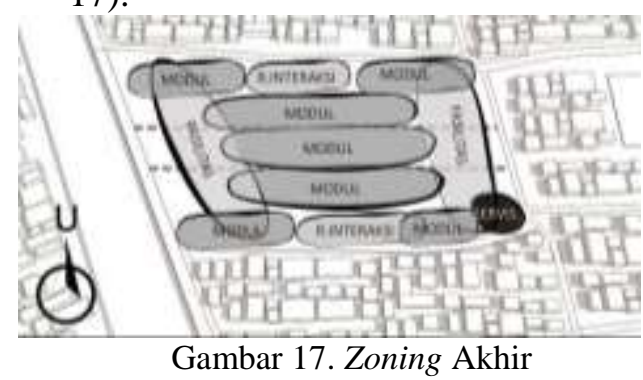

Analisis tata massa merespon beberapa hal terkait, seperti tata letak ME dan SE, zoning akhir, serta 
kondisi kawasan sekitar (Gambar 18).
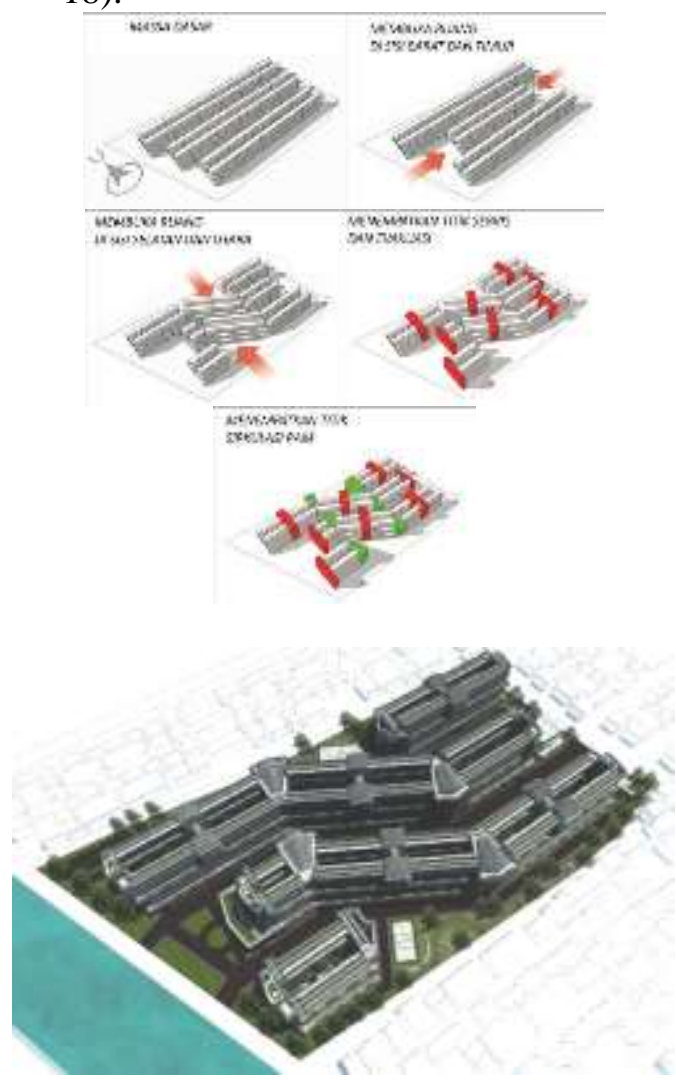

Gambar 18. Transformasi dan Hasil Tata Massa (Eksterior)

G. Analisis Struktur Analisis struktur sebagai elemen penunjang modul hunian.

1. Tujuan :

Mendapatkan sistem struktur pada modul hunian yang sesuai dengan karakter modul hunian

2. Dasar Pertimbangan :

Sistem yang mudah diterapkan pada modul, mewadahi karakter bangunan, material yang digunakan adalah material dengan karakter yang mampu mewadahi eksplorasi setiap warga di waktu yang akan datang.

3. Proses Analisis :

Pada struktur rangka setidaknya terdapat 3 model struktur (Gambar 19), yaitu:

a. Modular (A)

Setiap unit memiliki modul yang sejenis dan penempatannya mengikuti ruang pada struktur rangka. b. Struktur kantiliver (B)

Struktur ini terdapat pada unit hunian dengan ruang jalan di bawahnya. Hal ini diterapkan guna meminimalisir penggunaan kolom pada ruang jalan.

c. Waffle structure (C) Jenis struktur ini terletak pada setiap unit hunian, di mana waffle structure memiliki peran dalam mewadahi fleksibilitas tata ruang unit hunian.

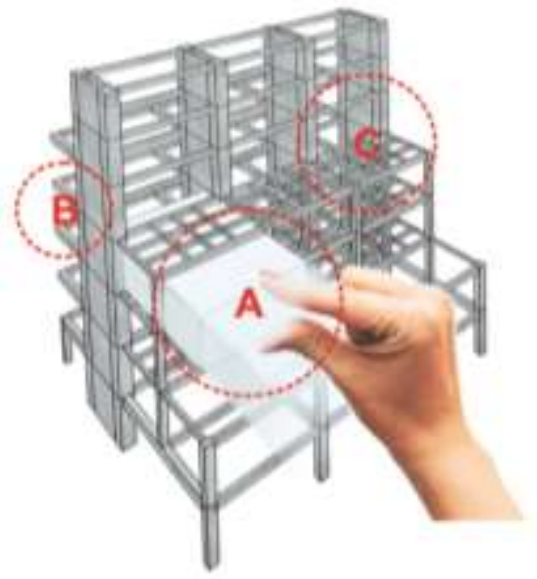

Gambar 19. Struktur Modul Hunian

\section{H. Analisis Utilitas}

Utilitas menjadi elemen penunjang lain sekaligus sebagai elemen yang melengkapi kebutuhan dan perawatan modul hunian.

1. Tujuan :

Mendapatkan sistem utilitas pada modul hunian khususnya sistem distribusi air serta penyaluran sampah.

2. Dasar Pertimbangan :

Sistem yang tersedia di setiap lantai modul hunian, sistem pengolahan air memanfaatkan air hujan serta memanfaatkan kembali grey water, sampah dapat diolah terlebih dahulu.

3. Proses Analisis :

Sistem distribusi air menggunakan sistem pemanfaatan kembali, baik itu air hujan maupun grey water (Gambar 20). 


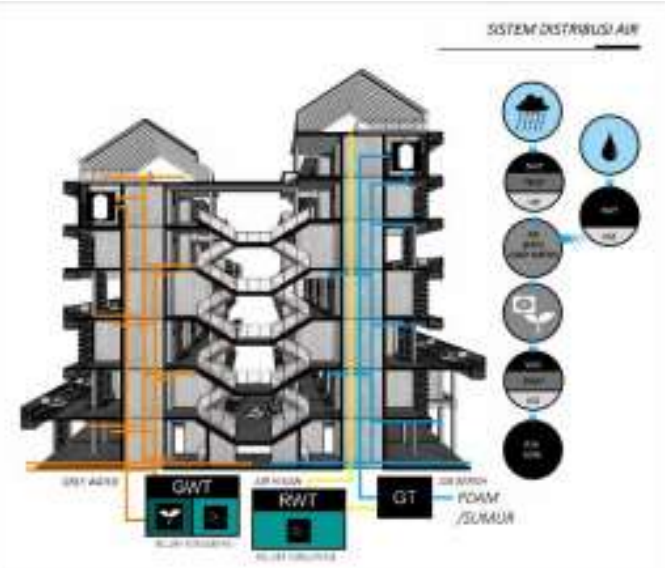

Gambar 20. Sistem Distribusi Air

Sistem penyaluran sampah menggunakan konsep "sampah adalah uang" di mana setiap unit hunian yang akan menyalurkan sampahnya ke bank sampah secara mandiri, untuk kemudian ditukarkan dengan sesuatu yang lebih bernilai lebih. Bank sampah sendiri akan mengolah dan mendistribusikan sampah yang tidak dapat diolah ke Tempat Pembuangan Akhir (TPA) Kota Jakarta (Gambar 21). Pengolahan sampah yang dilakukan pun meliputi dua hal, yaitu pengolahan sampah organik dan pengolahan sampah non-organik. Keduanya akan dilakukan secara mandiri dengan melibatkan warga Kampung Kalianyar sebagai pelaku industri pengolahan sampah. Selain dapat menjadikan kampung yang mandiri, hal ini tentu dapat meningkatkan nilai ekonomi di Kampung Vertikal Kalianyar

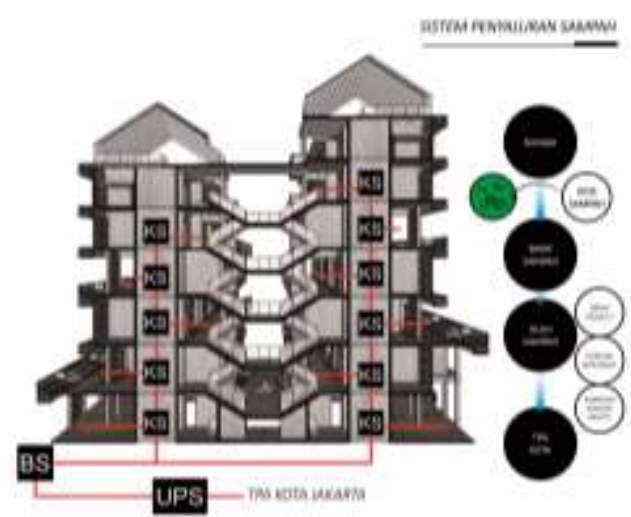

Gambar 21. Sistem Penyaluran Sampah

\section{KESIMPULAN (KONSEP DESAIN)}

Berdasarkan hasil analisis perencanaan dan perancangan yang dilakukan, maka diperoleh konsep desain Kampung Vertikal Kalianyar dengan Pendekatan Arsitektur Perilaku yang diharapkan mampu mewadahi karakter Kampung Kalianyar.

Lokasi : Kelurahan Kalianyar,

Kecamatan Tambora, Jakarta Barat

Luas Lahan $\quad: \pm 34.000 \mathrm{~m}^{2}$

Daya Tampung : 826 Kepala Keluarga

Fungsi : Hunian Sosial

Sebagai sebuah hunian sosial yang berada dalam lingkungan yang dinilai kurang kondusif, Kampung Vertikal Kalianyar hadir sebagai sebuah perwujudan desain dalam mengatasi permasalahan kepadatan penduduk serta tidak teraturnya tata ruang Kota Jakarta. Konsep desain yang diterapkan adalah perwujudan desain yang mewadahi karakter kampung melalui Pendekatan Arsitektur Perilaku. Konsep desain dengan Pendekatan Arsitektur Perilaku diwujudkan dalam beberapa hal, seperti penerapan karakter kampung melalui proses pemetaan (mapping), penerapan prinsip kenyamanan interaksi melalui standar kenyamanan skala dan jarak, dan penerapan perilaku beragam warga kampung pada fleksibilitas desain ruang.

Kampung Kalianyar memiliki karakter yang tidak dapat ditinggalkan pada unit hunian yang baru. Karakter seperti kehidupan di ruang jalan, diwujudkan dalam desain modul hunian yang memiliki ruang jalan di setiap ruas lantai seperti halnya kondisi eksisting kampung (Gambar 22).

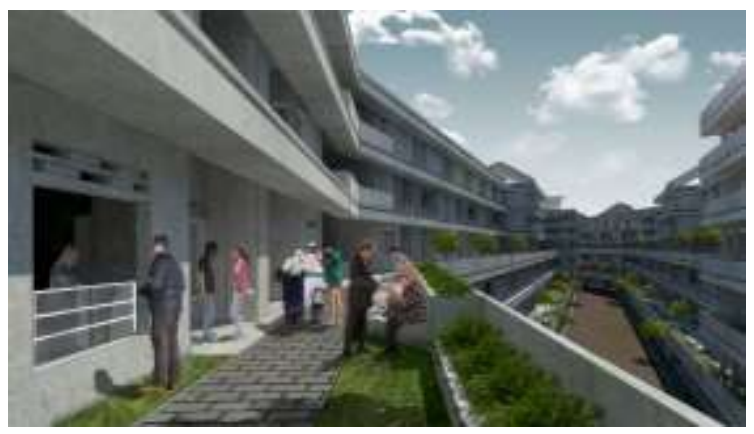

Gambar 22. Kehidupan Ruang Jalan

Sarana dan prasarana penunjang yang dinilai belum optimal akan diwujudkan dalam desain yang efisien dengan konsep penggabungan fungsi, seperti masjid yang 
digabungkan dengan fungsi balai warga (Gambar 23) dan pasar lingkungan yang digabungkan dengan ruang interaksi atau ruang publik (Gambar 24).

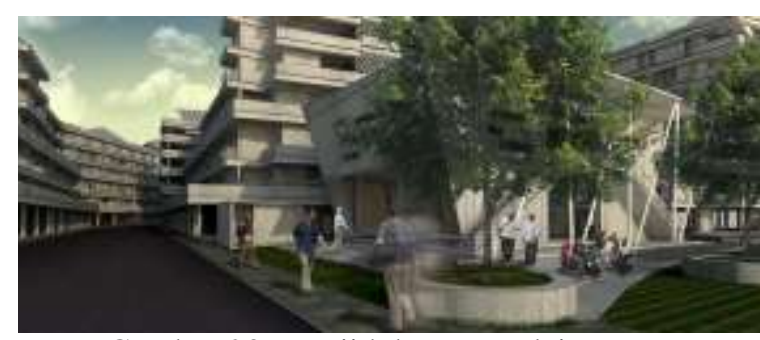

Gambar 23. Masjid dengan Balai Warga

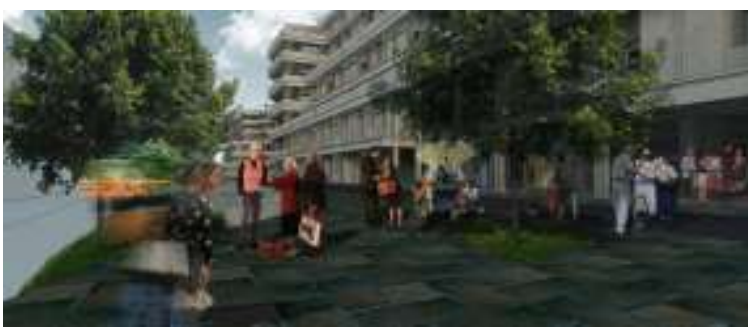

Gambar 24. Ruang Interaksi

Kampung Vertikal Kalianyar dengan sendirinya akan mencerminkan karakter Kampung Kalianyar melalui perwujudan desain yang berlandaskan pada hasil pengamatan dan pemetaan yang dilakukan. Setidaknya karakter seperti ruang jalan dan area industri atau komersial rumahan terwujud dalam zonasi pada setiap modulnya. Hal ini mampu mewujudkan kesan kampung yang berbeda dengan kampung yang lainnya (Gambar 25).

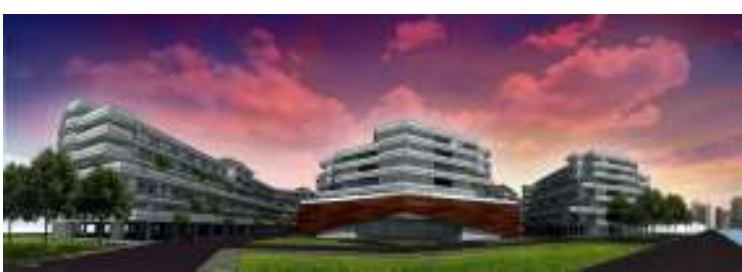

Gambar 25. Tampak Depan Kampung Vertikal Kalianyar

\section{REFERENSI}

Budiharjo, Eko. 2004. Sejumlah Masalah Perkampungan Kota. Bandung: Alumni

Turner J.C,. 1985. Housing by People. New York: MIT Press.

Marcella, Joyce. 2004. Arsitektur dan Perilaku Manusia. Jakarta:Grasindo
Rujak Center For Urban Studies. 2011. Kata Fakta Jakarta. Jakarta.

Sadana, Agus S. 2014. Perencanaan Kawasan Permukiman. Yogyakarta:Graha Ilmu

Menteri Pekerjaan Umum Nomor : 05/Prt/M/2007 Tentang Pedoman Teknis Pembangunan Rumah Susun Sederhana Bertingkat Tinggi. 2007. Jakarta

Undang-Undang Nomor 16 tentang Rumah Susun. 1985. Jakarta

Undang-undang Nomor 26 Tahun 2007 tentang www.beritasatu.com

www.katadata.com

www.kectambora.com 